\title{
Influence of some physical and biological factors on the density and vertical distribution of Atlantic halibut Hippoglossus hippoglossus eggs
}

\author{
Tore Haug $^{1}$, Elin Kjørsvik ${ }^{2} \&$ Per Solemdal ${ }^{3 *}$ \\ ${ }^{1}$ Department of Marine Biology, Tromse Museum, University of Tromsø, P.O. Box 2550, N-9001 Tromse, Norway \\ ${ }^{2}$ Institute of Biology and Geology, University of Tromse, P.O. Box 3085 Guleng, N-9001 Tromsø, Norway \\ ${ }^{3}$ Institute of Marine Research, Directorate of Fisheries, P.O. Box 1870, N-5011 Bergen-Nordnes, Norway
}

\begin{abstract}
Atlantic halibut Hippoglossus hippoglossus (L.) eggs were sampled using a Tucker trawl and a MOCNESS-sampler at 3 selected localities in North Norway. The specific density of the eggs was determined in a density-gradient column. The eggs were found to achieve higher specific density with increasing age. In areas with a horizontally stable, clearly defined pycnocline (Andfjord and Søroysund), the vertical distribution of eggs was characterized by a unimodal egg distribution. Furthermore, the older eggs were found at higher average capture salinities than younger eggs, i.e. they were distributed in relation to their neutral buoyancy. In an area with a horizontally more variable and less defined pycnocline (Malangen), the pattern of vertical distribution of eggs was less distinct, often with polymodal egg distributions. In this hydrographically variable system, no heterogeneity in the distribution of the various egg developmental stages could be discerned. In Malangen, thus, it is proposed that the vertical distribution of halibut eggs is most strongly influenced by physical factors.
\end{abstract}

\section{INTRODUCTION}

Studies of ichthyoplankton occupy a prominent position in world fisheries, and are, for example, the main technique for assessment of the biomass of spawning populations of fishes and productivity of different generations. Quantitative studies of ichthyoplankton require adequate information on both vertical and horizontal dispersion of eggs and larvae. To understand the horizontal dispersion of ichthyoplankton, which is determined by currents at different depths, proper knowledge about the vertical distribution dynamics of eggs/larvae is needed. This knowledge will include data on natural conditions e.g. salinity, temperature, available food organisms, and predators of the youngest stages, experienced by potential aquaculture/sea ranching species, thus enabling rearing investigators to chose suitable experimental conditions.

Studies of the vertical distribution of fish eggs are often hampered by poor vertical resolution sampling

\footnotetext{
- Authorship equal
}

methods. Technical advances in the development of multiple-net plankton samplers has, however, enabled collection of more detailed and precise information on the vertical distribution of ichthyoplankton (e.g. Coombs et al. 1981, Haug et al. 1984, Solemdal \& Ellertsen 1984, Coombs et al. 1985). Similarly, improvements of density-gradient columns has allowed better estimates of the neutral buoyancy of live fish eggs (see Coombs 1981).

The buoyancy and vertical distribution of Atlantic halibut Hippoglossus hippoglossus (L.) eggs has been determined by Haug et al. (1984). The eggs were primarily found floating in intermediate water layers. It was proposed that their vertical distribution was determined by their specific gravity and that this was closely correlated to seawater density. The present paper presents results from more detailed studies of how the neutral buoyancy and vertical distributions of halibut eggs are influenced by biological factors, such as the stage of development, and by the physical oceanography at selected spawning grounds in North Norway. This was done by chosing sampling sites with different hydrographical conditions for the investigations. 


\section{MATERIALS AND METHODS}

The vertical distribution of halibut eggs was studied in Andfjord, Malangen and Sørøysund, 3 well-known halibut spawning grounds in North Norway (Fig. 1). Sampling took place in 1984 and 1985 in late January and early February as this is the period of most intensive spawning in certain areas of North Norway (Tjemsland 1960, Kjørsvik \& Haug 1985).

The main reason for chosing several sampling sites was to achieve samples from areas with different hydrographical regimes. In the analyses, the distribution of eggs in different hydrographical systems were thus compared with respect to vertical stratification. By well-stratified systems we mean localities characterized by a very conspicuous density stratification, i.e. a well-defined pycnocline. A less stratified system in our terminology lacks such a well-defined pycnocline. During winter the relation between temperature and salinity is quasi-linear, and therefore the pycnocline
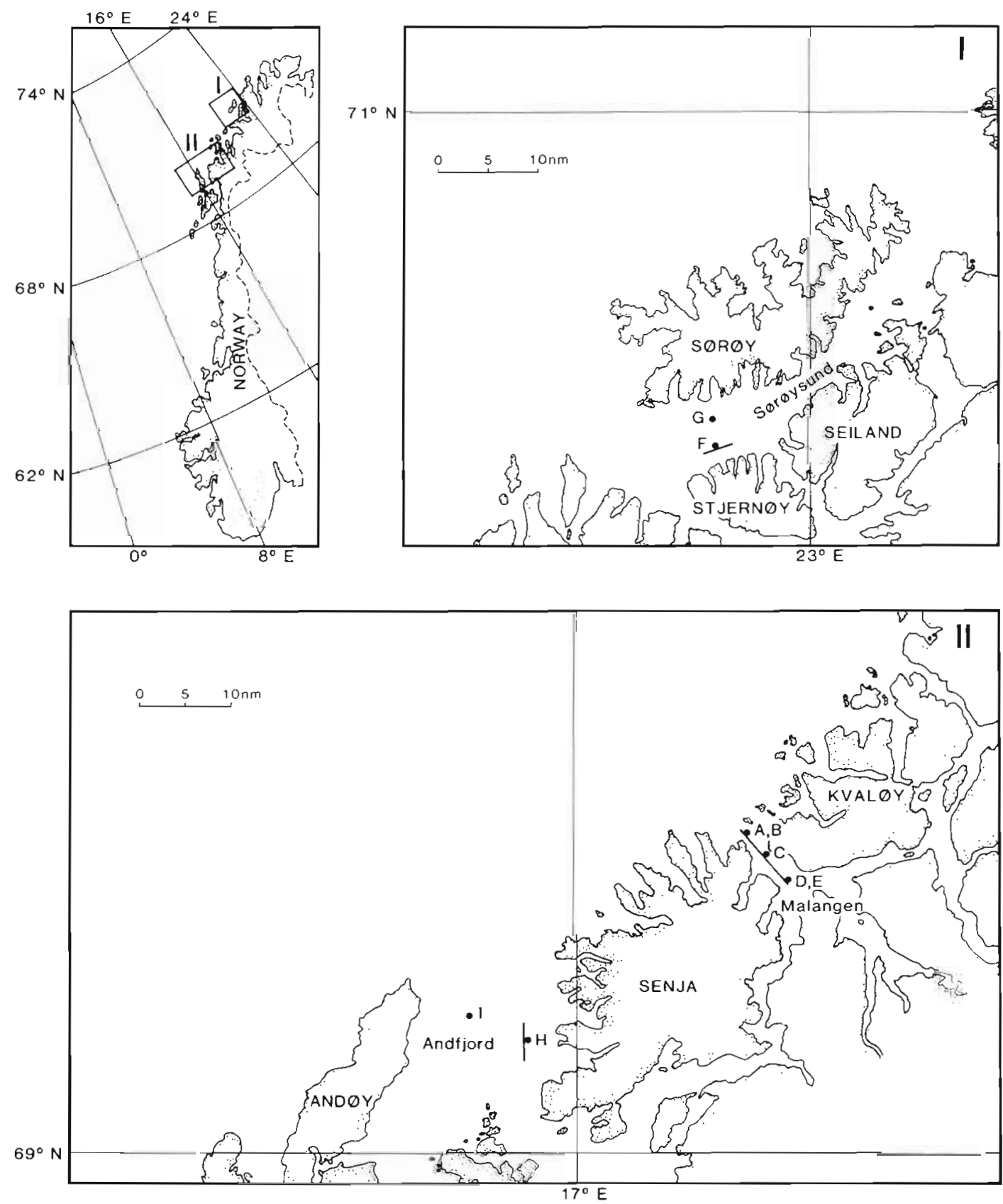

Fig. 1. Sampling localities Andfjord and Malangen (I) and Sorøysund (II) in North Norway. Hydrographical sections are indicated by lines; letters A to I refer to stations where vertical distributions of seawater density and halibut egg concentrations were determined (see Fig. 2) 
coincides with the halocline and thermocline in the areas of investigation (Svein Sundby, Institute of Marine Research, Directorate of Fisheries, Bergen, Norway, pers. comm.).

The vertical distribution of eggs was primarily determined using a MOCNESS multiple opening-closing net and environmental sensing system (Wiebe et al. 1976) fitted with 8 nets (mesh size $0.33 \mathrm{~mm}$, opening $1 \mathrm{~m}^{2}$ ). Plankton was sampled at selected depths while a computer, connected to an in situ flowmeter, calculated the volume of seawater filtered through each net. Each sampling net was towed for 30 or $60 \mathrm{~min}$. Gener ally, the MOCNESS was towed in various directions in the sampling area, starting with the greatest depths and elevating the gear to a new depth every time a new net was opened.

Some extra MOCNESS tows were made at selected depths of known salinity to provide more eggs for the studies of neutral buoyancy. For the same purpose, eggs sampled in Malangen and Sørøysund in 1982 and 1983 (see Haug et al. 1984) and in Malangen in 1983 to 1985 (Kjørsvik \& Haug 1985) were included in the present analysis. In these surveys Tucker-trawl (mesh size $1.0 \mathrm{~mm}$, opening $1 \mathrm{~m}^{2}$ ) tows were also made during sampling. A Simrad trawl eye was mounted onto the Tucker-trawl to ensure that sampling took place at the desired depths.

The total number of MOCNESS hauls performed at the various depths in 1984 and 1985 is summarised in Table 1.

Closely linked to all egg sampling were recordings of temperature and salinity every $5 \mathrm{~m}$ from surface to bottom using a Neill Brown CTD-sonde connected to a Nord-10 computer. A more detailed description of the CTD-sonde/computer system and also the Tucker trawl/Simrad trawl eye used in these investigations is given by Hopkins et al. (1982). The static stability of

Table 1. Total number of MOCNESS tows taken at various depths during the 1984 and 1985 surveys

\begin{tabular}{|cccc|}
\hline $\begin{array}{c}\text { Depth } \\
(\mathrm{m})\end{array}$ & $\begin{array}{c}\text { Malangen } \\
1984\end{array}$ & $\begin{array}{c}\text { Sørøysund } \\
1984\end{array}$ & $\begin{array}{c}\text { Andfjord } \\
1985\end{array}$ \\
\hline 10 & 1 & & 1 \\
50 & & 2 & 1 \\
75 & 4 & 2 & 2 \\
100 & 5 & 2 & 3 \\
125 & 5 & 2 & 11 \\
150 & 6 & & 16 \\
175 & 6 & 2 & 3 \\
200 & 6 & & 2 \\
225 & 7 & & 1 \\
250 & 6 & & 1 \\
275 & & & \\
300 & & & \\
\hline
\end{tabular}

the water masses was expressed by the squared BruntVaisälä frequency, $\mathrm{N}^{2}$ (see Phillips 1977), computed for every $10 \mathrm{~m}$ depth interval at the 3 sampling sites.

Each egg was allocated an individual collection salinity which was defined as the salinity registered using the CTD-sonde at the depth where the egg was collected. The egg stages were determined according to Rollefsen (1934) and Lonning et al. (1982). The following developmental stages were used to classify the age of the eggs: Stage I, blastulae, 0 to $3 \mathrm{~d}$; Stage II, gastrulae, 4 to $10 \mathrm{~d}$; Stage III, embryos after closure of blastopores, 11 to $18 \mathrm{~d}$. Whenever possible, the developmental stages were determined for live eggs on board. These eggs were kept in jars containing seawater and, as soon as possible, transferred to a densitygradient column (Coombs 1981) where the density, $\sigma_{t}$ of each egg was determined. On the basis of this $\sigma_{t}$ and the temperature in the column, the salinity of neutral buoyancy of each egg was calculated. Some of the eggs were fixed in a solution of $2.5 \%$ glutaraldehyde and $2.5 \%$ formaldehyde in $0.05 \mathrm{~mol} \mathrm{l}^{-1}$ cacodylate buffer $\left(\mathrm{pH}=7.2,350\right.$ mosmol $\mathrm{kg}^{-1}$ ). After ca $24 \mathrm{~h}$ they were transferred to $0.05 \mathrm{~mol} \mathrm{l}^{-1}$ cacodylate buffer for storage and later determination of developmental stage.

Statistics were used to test for differences in collection salinities and neutral buoyancy salinities among developmental egg stages using BMDP programs (BMDP1V, 1-way ANOVA; Dixon 1981).

\section{RESULTS}

\section{Hydrography and vertical distribution of eggs}

During the 1984 egg survey in Malangen, the CTDrecordings revealed no well-defined pycnocline with the seawater density increasing quite evenly from $25 \mathrm{~m}$ down to ca $200 \mathrm{~m}$ depth (Fig. $2 \mathrm{~A}$ to $\mathrm{E}$ ). This impression of weak stratification was confirmed also from relatively low Brunt-Vaisälä frequencies at all depth intervals (never exceeding $5.1 \times 10^{-5} \mathrm{~s}^{-2}$; Fig. 4), and from the salinity section taken from the inner to the outer area (Fig. 3). The latter also indicated considerable horizontal variation in the depth distribution of isohalines. Salinity ranged from $33.6 \%$ in the surface layers to $34.5 \%$ in the deeper strata. Given this situation, the distribution of halibut eggs was quite variable with marked peaks in egg concentration occurring in some samples (Fig. 2A, E) while in others secondary and even tertiary egg maxima were observed (Fig. 2B to D).

The waters surveyed in Sørøysund in 1984 and in Andfjord in 1985 were characterized by a very conspicuous density stratification. Thus, in both these 
SEA WATER DENSITIES ( $6 \mathrm{t}$ )
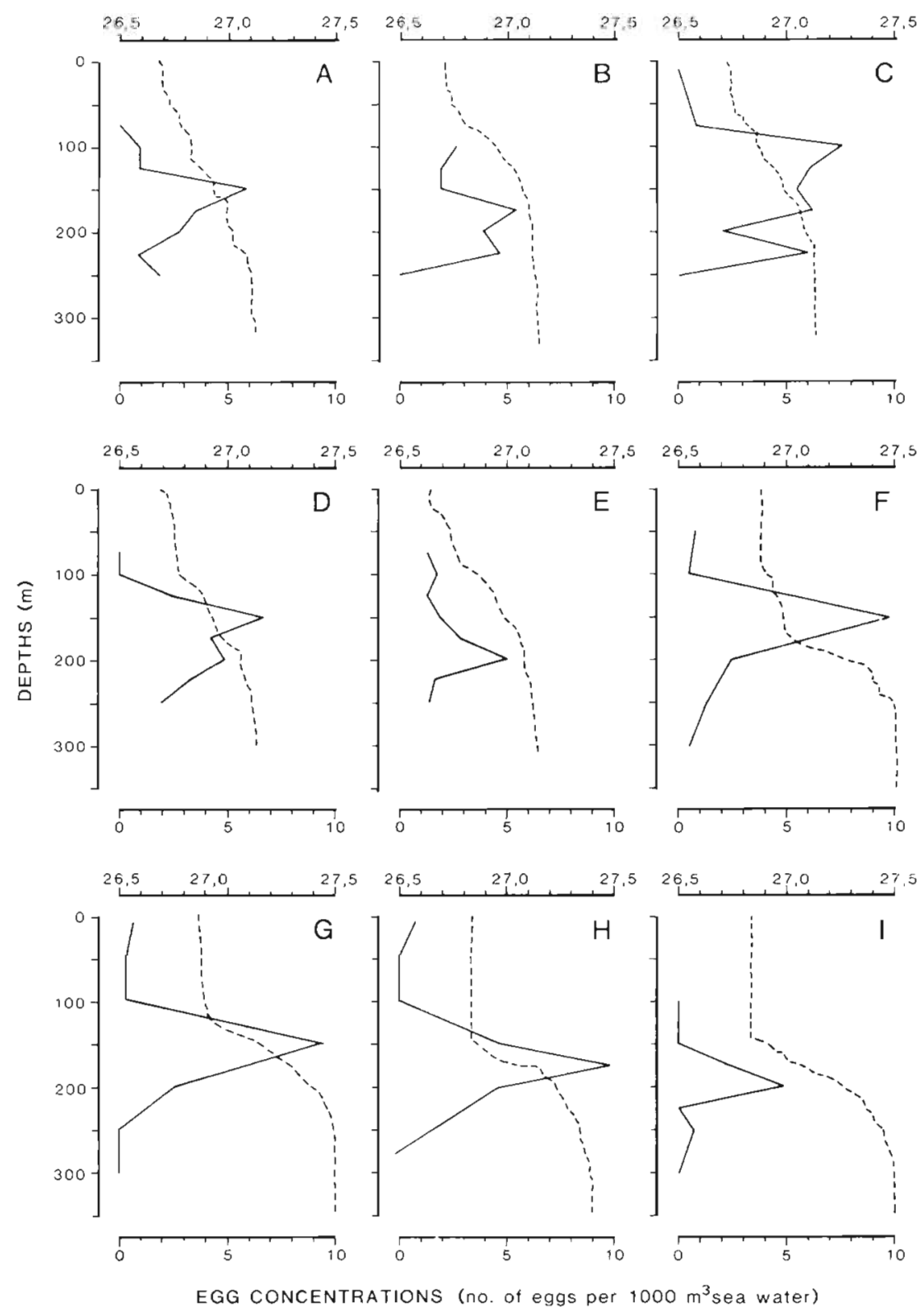

Fig. 2. Vertical distribution of seawater density $\left(\sigma_{1}\right.$, dashed curves) and halibut egg concentrations (solid curves) as determined in Malangen 1984 (Stn A and D, 14 Feb; Stn C, 15 Feb; Stn $B$ and E, 16 Feb), Sorøysund 1984 (Stn F, 26 Jan; Stn G, 31 Jan). and Andfjord 1985 (Stn H, 31 Jan; Stn I, 3 Feb). Hydrographic data were recorded either immediately before or after the egg collections

areas a well-defined pycnocline/halocline was present (Fig. 2F to I \& 3). Above and below these pycnoclines, low Brunt-Vaisälä frequencies were recorded (Fig. 4), while the pycnocline depth intervals were characterized by high values with the maximum value in Andfjord $\left(2.2 \times 10^{-4} \mathrm{~s}^{-2}\right)$ clearly exceeding that recorded in Sørøysund $\left(1 \times 10^{-4} \mathrm{~s}^{-2}\right)$. Also, the horizontal variations in depth distribution of isohalines were very small, especially within the pycnocline/ halocline (Fig. 3). The halibut egg distribution was characterized by one very marked peak in egg concentration, usually occurring either just above (Fig. 2F) or within (Fig. 2G to I) the pycnocline.

\section{Collection salinities of eggs from a weakly stratified system}

The hydrography of the Malangen locality in 1984 is clearly characterized as only weakly stratified (Fig. 2, 3 \& 4), and it is also subjected to both temporal (Fig. 2) and horizontal (Fig. 3) changes in the isohalines. Lack of a strongly defined pycnocline was also evident at this locality during both the 1983 (Haug et al. 1984) and 1985 (Kjørsvik \& Haug 1985) investigations from which some of the sampled eggs are included in the present analyses.

Collection salinities were recorded for 334 eggs 

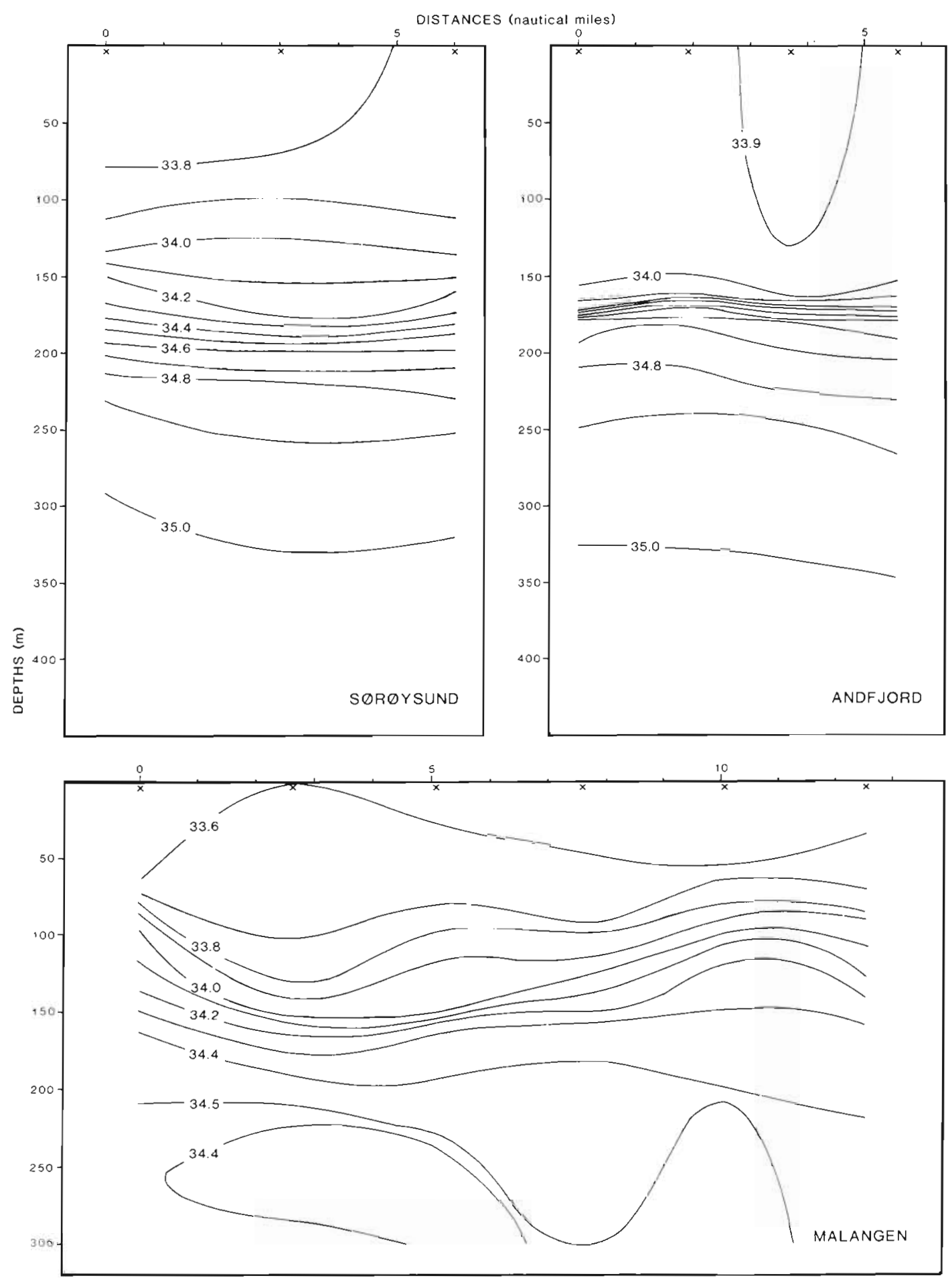

Fig. 3. Salinity $(\%)$ sections taken in the areas where vertical distribution of halibut egg concentrations was determined. Sørøysund: 3 CTD-stations from east to west down to $350 \mathrm{~m}$ on $26 \mathrm{Jan} 1984$. Andfjord: 4 CTD-stations from south to north down to $350 \mathrm{~m}$ on $31 \mathrm{Jan}$ 1985; Malangen: 6 CTD-stations from the inner to the outer areas of the fjord down to $300 \mathrm{~m}$ on $13 \mathrm{Feb} 1984$. The positions of the sections are shown in Fig. 1. CTD-stations indicated by crosses 


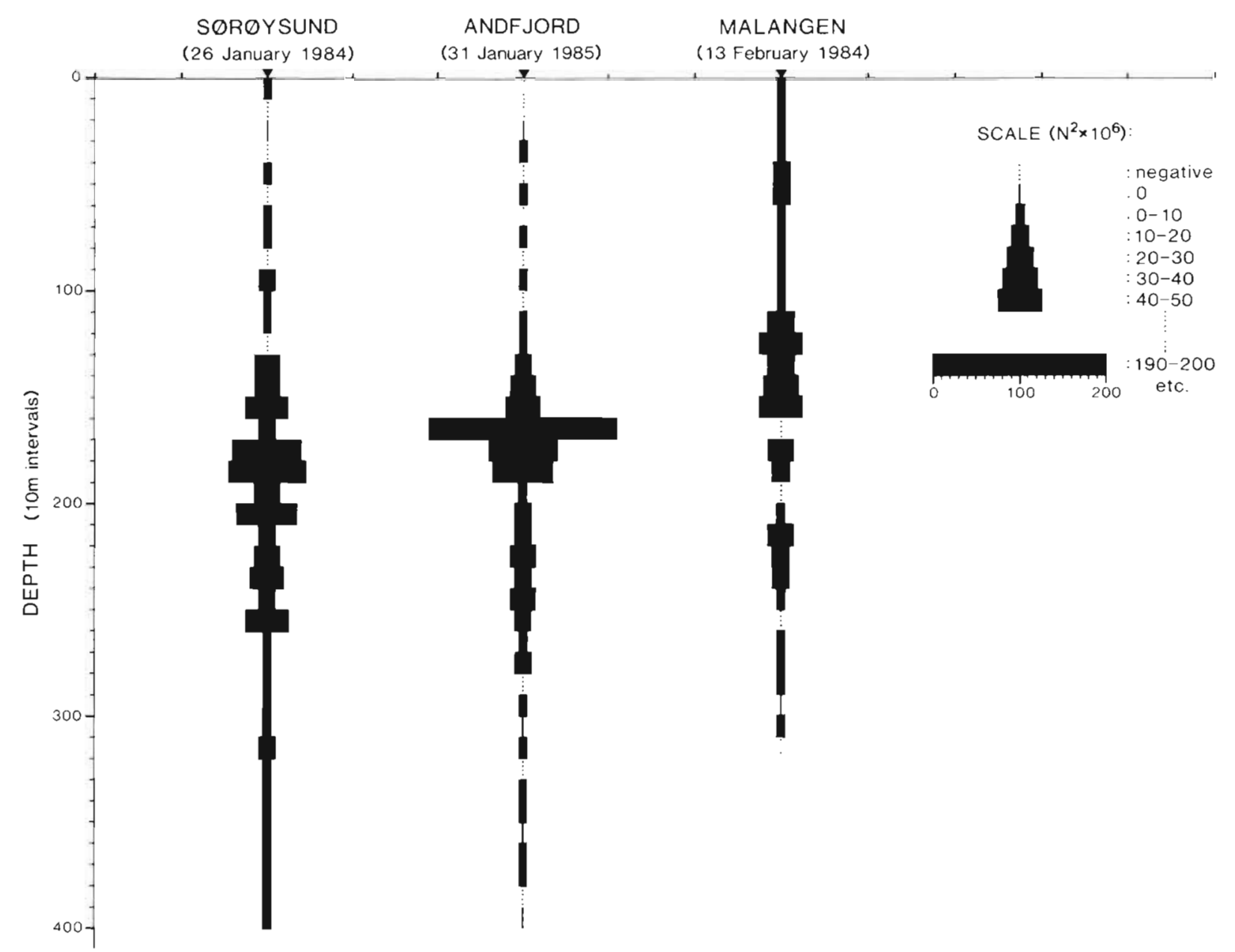

Fig. 4. Squared Brunt-Vaisälä frequency $\left(\mathrm{N}^{2}\right.$, given in $\left.\mathrm{s}^{-2}\right)$ in each $10 \mathrm{~m}$ depth interval in Sørøysund, Andfjord and Malangen. Note that the scale is $\mathrm{N}^{2} \times 10^{6}$

caught in the variable Malangen system between 1983 and 1985 (Fig. 5). A 1-way ANOVA applied to the material revealed no significant heterogeneity among the mean collection salinities of the 3 developmental egg stages ( $p>0.05$, Table 2).

\section{Collection salinities of eggs from well-stratified systems}

Both Sørøysund and Andfjord could be classified as well-stratified and quite stable hydrographical systems in 1984 and 1985 (Fig. 2, 3 \& 4). As revealed from the squared Brunt-Vaisälä frequency (Fig. 4), the stratification in Andfjord was especially strong and localized to a very narrow depth interval. During the Sørøysund investigations in 1982 and 1983, from which some of the sampled eggs are included in the present analyses, the general impression of the hydrographical situation were the same as in 1984, i.e. well-stratified and stable (Haug et al. 1984).

Collection salinities were recorded for a total of 154 eggs caught in the well-stratified systems of Sørøysund (1982, 1983 and 1984) and Andfjord (1985) (Fig. 5). Applying a 1-way ANOVA upon the Andfjord material, it was evident that the observed collection salinities of the various egg stages was significantly different ( $p=0.015$, Table 2). The associated t-test matrix revealed that this difference was caused by values of Egg Stage III being significantly higher than those of both Stage I $(p=0.011)$ and Stage II $(p=$ 0.008 ). No significant heterogeneity was observed between the capture salinity values of Stages I and II ( $p>0.05$ ). When similar statistics were applied to the Sørøysund material, it appeared, however, that the observed change in capture salinity with egg age at this locality was not statistically significant $(p>0.05$, Table 2). 


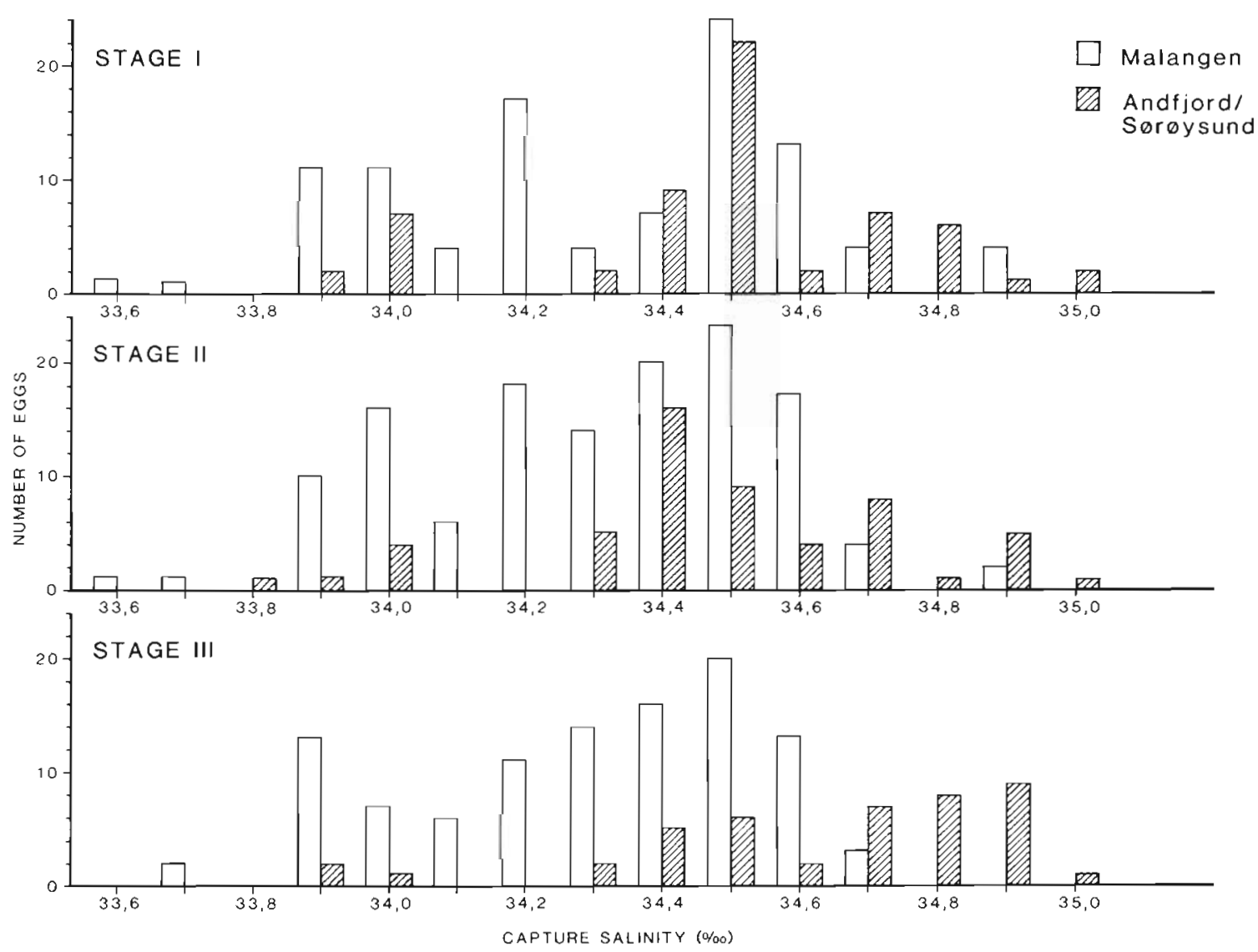

Fig. 5. Collection salinities as observed for the various halibut egg stages in Malangen and Andfjord/Sørøysund

Table 2. Mean capture salinities and mean salinity of neutral buoyancy ( \pm SD) for various developmental egg stages, and results from 1-way ANOVAs among the different egg stage means. $\mathrm{N}$ : number of eggs

\begin{tabular}{|c|c|c|c|c|c|c|c|c|}
\hline \multirow{3}{*}{$\begin{array}{c}\text { Developmental } \\
\text { stages }\end{array}$} & \multicolumn{6}{|c|}{ Mean collection salinities } & \multirow{2}{*}{\multicolumn{2}{|c|}{$\begin{array}{l}\text { Mean salinity of } \\
\text { neutral buoyancy } \\
\text { All areas pooled }\end{array}$}} \\
\hline & & \multicolumn{2}{|l|}{ Andfjord } & \multicolumn{2}{|l|}{ Sørøysund } & & \\
\hline & $\%$ & $N$ & $\%$ & $\mathrm{~N}$ & $\%$ & $N$ & $\%$ & $\mathrm{~N}$ \\
\hline I & $34.31 \pm 0.28$ & 96 & $34.45 \pm 0.25$ & 45 & $34.46 \pm 0.38$ & 12 & $33.91 \pm 0.40$ & 20 \\
\hline II & $34.29 \pm 0.25$ & 132 & $34.44 \pm 0.19$ & 36 & $34.53 \pm 0.33$ & 18 & $34.05 \pm 0.48$ & 59 \\
\hline III & $34.28 \pm 0.24$ & 106 & $34.60 \pm 0.22$ & 26 & $34.64 \pm 0.34$ & 17 & $34.41 \pm 0.50$ & 65 \\
\hline All stages & $34.29 \pm 0.27$ & 334 & $34.48 \pm 0.23$ & 107 & $34.55 \pm 0.35$ & 47 & $34.19 \pm 0.52$ & 144 \\
\hline \multicolumn{9}{|c|}{ One-way ANOVAs among developmental stages } \\
\hline $\mathrm{F}$ & 0.252 & & 4.356 & & 0.999 & & 12.846 & \\
\hline $\mathrm{df}_{1}$ & 2 & & 2 & & 2 & & 2 & \\
\hline $\mathrm{df}_{2}$ & 331 & & 104 & & 44 & & 141 & \\
\hline $\mathrm{p}$ & $>0.05$ & & $=0.015$ & & $>0.05$ & & $<0.001$ & \\
\hline
\end{tabular}

\section{Salinity of neutral buoyancy}

The salinity of neutral buoyancy was recorded for a total of 144 eggs (Fig. 6). A 1-way ANOVA revealed a very significant degree of heterogeneity in the data $(p<0.001$, Table 2). The associated t-test matrix re- vealed that this was due to Stage III eggs being neutrally buoyant at significantly higher salinities than either Stage I $(p<0.001)$ or Stage II $(p<0.001)$ eggs. There was no significant difference between the salinity of Stage I and Stage II eggs $(p>0.05)$. 


\section{Relation between salinity of neutral buoyancy and collection salinity}

For eggs from Andfjord and Sorøysund the salinity of neutral buoyancy was in most cases less than the collection salinity (Fig. 7), i.e. the eggs were less dense than the seawater in which they were found. In Malangen this trend was not observed, as the range of salinities of neutral buoyancy was generally wider for the specific capture salinities, i.e. eggs were both lighter and heavier than the seawater in which they were found.

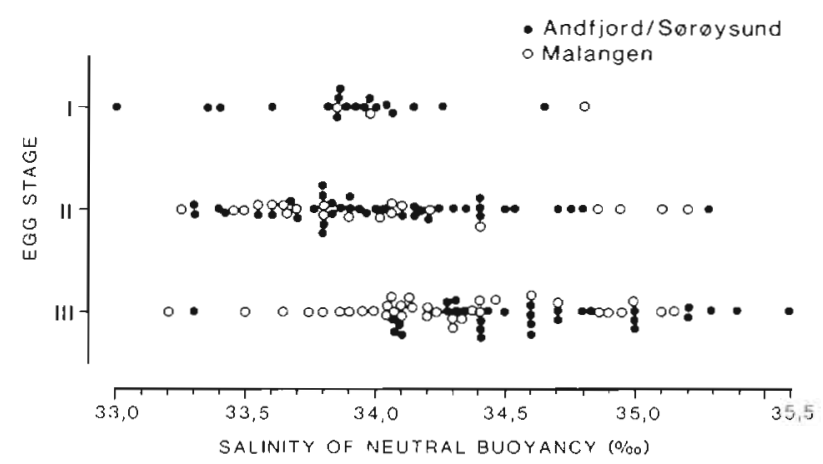

Fig. 6. Salinity of neutral buoyancy of 144 halibut eggs at various developmental stages

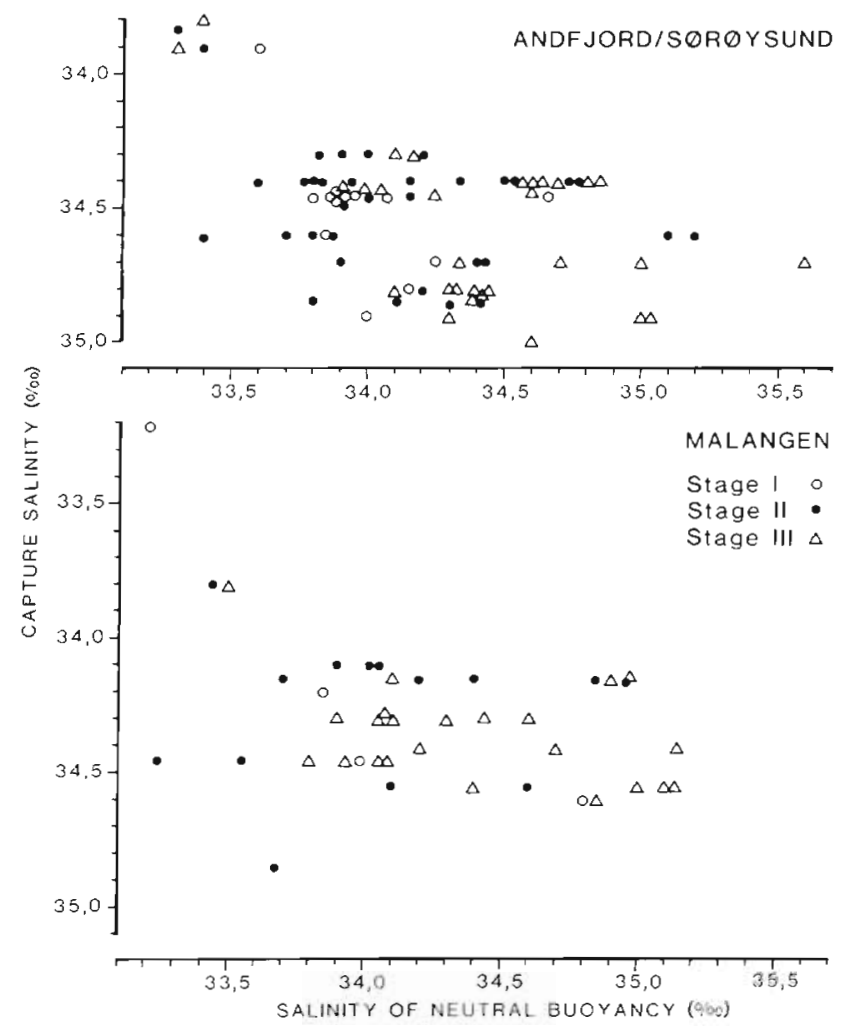

Fig. 7. Relation between salinity of neutral buoyancy and capture salinity of 144 eggs from Malangen and Andfjord/ Sørøysund

\section{DISCUSSION}

The different hydrographical conditions on the halibut spawning areas investigated provided a good opportunity of examining how these factors influence the vertical distribution of the eggs. While discussing the results it is necessary to be aware of the difference in accuracy of the sampling methods. The CTD-sonde gives an absolute measure of hydrographical data at various depths at one restricted point. The trawling gear, however, was hauled along a certain distance close to this point, but never at the same time as the CTD-recording. Furthermore, variations in winds and currents always hampered the possibilities of sampling at exactly the desired depths during each haul.

Since there is a quasi-linear relation between salinity and temperature (and thus also seawater density) in the area of investigation (Svein Sundby, Institute of Marine Research, Directorate of Fisheries, Bergen, Norway, pers. comm.), the neutral buoyancy discussion is restricted to the salinity.

In the neutral buoyancy measurements it often appeared that the eggs were less dense than the seawater in which they were originally found (Fig. 7). This was especially evident from the Andfjorden/Sørøysund samples, while data for eggs from Malangen were more scattered. The vertical movement of fish eggs after spawning is dependent to a large extent on the effects of passive drift toward the salinity of neutral buoyancy, and redistribution due to mixing within the water column (Sundby 1983). Light eggs may therefore be eggs ascending towards their position of neutral buoyancy. Applying the equations describing Stoke's drift of passive particles in a fluid (Sundby 1983), it seems that halibut eggs will take from 2 to $4 \mathrm{~d}$ to ascend from the bottom to their neutral buoyancy depth. From Table 2 it is evident that the discrepancies between the average salinity of neutral buoyancy and the collection salinity diminish with egg age resulting in a better correlation between salinity of neutral buoyancy and capture salinity for the oldest (Stage III) egg group.

Higher egg buoyancy compared to seawater density has also been observed for several other pelagic fish eggs (Sundnes et al. 1965, Solemdal 1970, Solemdal \& Sundby 1981, Coombs et al. 1985). It has been suggested (Coombs et al. 1985) that neutral buoyancy measurements may to some extent be underestimates of the true values due to the sampling method. In the present study eggs were brought from their collection salinities up through layers of decreasing salinity, and were subsequently held in seawater of surface salinity (10 to $15 \mathrm{~min}$ ) until they were put into the densitygradient column. Small changes in density of pelagic fish eggs can occur when they are transferred to differ- 
ent salinities (Kändler \& Tan 1965, Solemdal 1973). According to Coombs et al. (1985) such buoyancy adjustments towards the new salinity can take place within minutes.

Two main conclusions can be drawn from the present study:

(1) Halibut eggs spawned naturally achieve higher specific gravity with age (Fig. 5). In our previous paper (Haug et al. 1984), the number of eggs tested in the density-gradient column was probably too small $(\mathrm{n}=$ 40) to reveal any changes in neutral buoyancy with age. As we have accumulated more data on the neutral buoyancy of planktonic halibut eggs of various ages, we can now show that these eggs do become heavier during the last part of egg development. Similar observations have been made on the planktonic eggs of other fishes (Franz 1910, Sundnes et al. 1965, Alderdice \& Forrester 1968, Coombs et al. 1985).

(2) The vertical distribution of halibut eggs appears to be associated with the prevalent hydrography (Fig. 2 \& 3). Andfjord and Sørøysund were characterized by horizontally stable, strongly defined pycnoclines, and the vertical egg distribution had one clear peak. In both these areas, the older eggs were found at higher average collection salinities, i.e. at greater depth than the preceding stages. Although this was statistically significant only for the vertical egg distribution in Andfjord, the trend was clearly the same in both areas. Interestingly, although well-defined pycnoclines were present in both areas, there was a stronger stratification in Andfjord than in Sørøysund (Fig. 4). In Malangen, with a much less defined pycnocline and with much weaker stratification than in both other areas, the vertical distribution of eggs was less distinct, and no change in average collection salinity with egg developmental age was observed. This system also showed horizontal and temporal changes in the isohalines (Fig. $2 \& 3$ ). The more scattered vertical egg distribution in Malangen may therefore be due to convectional mixing of water masses, and/or sampling errors induced by collection of eggs through areas of differently located isohalines during the horizontal hauls. The lack of change in collection salinity with increasing egg age in Malangen agrees well with our previous study of the vertical distribution of Atlantic halibut eggs (Haug et al. 1984), where the majority of the eggs were sampled from Malangen.

From these conclusions, it becomes obvious that the more stable and well-stratified the hydrographic systems are (as for example observed in Andfjord and Søroysund), the larger are the chances that halibut eggs will be distributed according to their developmental biology, i.e. Stage III eggs, which were shown in the gradient column experiments to be the heaviest, are generally found at higher salinities than Stage I and II eggs. In the much less stratified Malangen system this is not the case; here hydrographic instability seems to have masked the differences in density between young and old eggs such that no heterogeneity in distribution of the various stages could be observed. Thus, in Malangen the vertical distribution of halibut eggs seems more strongly influenced by changes of physical factors.

Acknowledgements. Thanks are due to the crews of RV Ottar and RV Johan Ruud, and to L. Dalsbø. K. Lydersen, M.S. Nilsen, O. Nordgård, U. Normann, F. Pettersen, G. W. Pettersen, and B. Vaaja for technical assistance. S. Sundby and C. C. E. Hopkins provided critique of the manuscript, the latter also the English text. The study was financially supported by the Norwegian Fisheries Research Council (NFFR), project nos I405.02, I405.003, I401.14 and I401.023.

\section{LITERATURE CITED}

Alderdice, D. F., Forrester, C. R. (1968). Some effects of salinity and temperature on early development and survival of the English sole (Parophrys vetulus). J. Fish. Res. Bd Can 25: 495-521

Coombs, S. H. (1981). A density-gradient column for determining the specific gravity of fish eggs, with particular reference to the eggs of the mackerel (Scomber scombrus). Mar Biol. 63: 101-106

Coombs, S. H., Fosch, C. A., Keen, M. A. (1985). The buoyancy and vertical distribution of eggs of sprat (Sprattus sprattus) and pilchard (Sardina pilchardus). J. mar biol. Ass. U.K. 65: $461-474$

Coombs, S. H., Pipe, R. K., Mitchell, C. E. (1981). The vertical distribution of eggs and larvae of blue whiting (Micromesistius poutassou) and mackerel (Scomber scombrus) in the eastern North Atlantic and North Sea. Rapp. P.-v. Réun. Cons. int. Explor. Mer 178: 188-195

Dixon., W. J. (1981). BMDP Statistical Software. University of California Press, Berkeley, California

Franz, V. (1910). Untersuchungen über das specifische Gewicht der planktonischen Fischeier. Wiss. Meeresunters., N. F. (Abt. Helgoland) 9: 179-196

Haug, T., Kjørsvik, E., Solemdal, P. (1984). Vertical distribution of Atlantic halibut (Hippoglossus hippoglossus) eggs. Can. J. Fish. Aquat. Sci, 41: 798-804

Hopkins, C. C. E., Pettersen, F., Evans, R. A., Greenlaw, C. F. (1982). Zooplankton sound scattering layers in north Norwegian fjords: Specifications and functioning of the accoustical, data- and net sampling system. Sarsia 67: $187-199$

Kändler, R., Tan, E. O. (1965). Investigations on the osmoregulation in pelagic eggs of gadoid and flatfishes in the Baltic. I. Changes in volume and spec. gravity at different salinities. Coun. Meet. int. Counc. Explor. Sea, Baltic-Belt Seas Committee 43: 1-5

Kjørsvik, E., Haug, T. (1985). A preliminary report on the spawning season of the Atlantic halibut, Hippoglossus hippoglossus, in Malangen, North Norway. Coun. Meet. int. Counc. Explor. Sea C. M.-ICES/F 6: 1-18

Lønning, S., Kjørsvik, E., Haug, T., Gulliksen, B. (1982). The early development of the halibut, Hippoglossus hippoglossus (L.), compared with other marine teleosts. Sarsia 67: $85-91$ 
Phillips, O. M. (1977). Dynamics of the upper oceans. Cambridge University Press, Cambridge

Rollefsen, G. (1934). The eggs and larvae of the halibut (Hippoglossus vulgaris). K. norske Vidensk. Selsk. Forh. 7 (7): $20-23$

Solemdal, P. (1970). Intraspecific variations in size, buoyancy and growth of eggs and early larvae of Arcto-Norwegian cod, Cadus morhua L., due to parental and environmental effects. Coun. Meet. int. Counc. Explor. Sea C. M.-ICES/ F 28: 1-12

Solemdal, P. (1973): Transfer of Baltic flatfish to a marine environment and the long term effects on reproduction. Oikos 15 (Suppl.): 268-276

Solemdal, P., Ellertsen, B. (1984). Sampling fish larvae with large pumps; quantitative and qualitative comparisons with traditional gear. In: Dahl, E., Danielssen, D. S., Moksness, E., Solemdal, P. (ed.) The propagation of cod Cadus morhua L. Flødevigen rapportser. 1: 335-363
Solemdal, P., Sundby, S. (1981). Vertical distribution of pelagic fish eggs in relation to species, spawning behaviour and wind conditions. Coun. Meet. int. Counc. Explor. Sea C. M.-ICES/G 77: 1-22

Sundby, S. (1983). A one dimensional model for the vertical distribution of pelagic fish eggs in the mixed layer. Deep Sea Res. 30A: 645-661

Sundnes, G., Leivestad, H., Iversen, O. (1965). Buoyancy determinations of eggs from the cod (Gadus morhua L.). J. Cons. int. Explor. Mer 29: 249-252

Tjemsland, J. (1960). Kveita i Nord-Noreg. Cand. real. thesis, University of Bergen, Norway

Wiebe, P. H., Burt, K. H., Boyd, S. H., Morten, A. W (1976). A multiple opening/closing net and environmental sensing system for sampling zooplankton. J. mar. Res. 34: 313-326

This article was submitted to the editor; it was accepted for printing on August 29, 1986 